\title{
REPLICATION AND RECOVERY OF NUCLEAR DNA IN UV-IRRADIATED EGGS OF LYMNAEA STAGNALIS (MOLLUSCA, GASTROPODA)
}

\author{
V. LABORDUS and H. DEUMER \\ Zoological Laboratory, State University of Utrecht, 3508 TB Utrecht, The Netherlands
}

\begin{abstract}
SUMMARY
Synchronized and oriented egg cells of $L$. stagnalis have been irradiated with UV light during the G2 phase of the 2 nd cleavage cycle; next the egg cells were treated with caffeine $\left(3 \times 10^{-3} \mathrm{M}\right)$ for varying periods during the 2 nd and the 3 rd cleavage cycle. In a second experiment the egg cells were irradiated at the same stage in the G2-phase with different UV doses, and then treated with caffeine until the beginning of the 3rd cleavage. In the caffeine-treated egg cells the two cleavage cycles following irradiation appeared to be lengthened, whereas in non-caffeine controls only the first cleavage cycle after irradiation is longer. It is concluded that the extension of the 3rd cleavage cycle is to be attributed to a prolongation of the $S$ phase, which is not caused by an inhibition by caffeine of the initiation of the DNA synthesis. The results point to an effect of caffeine on the post-replication mode of repair; lesions in the DNA are not rendered innocuous in the presence of caffeïne. At the beginning of the next cleavage cycle these lesions still have an inhibiting effect on the progression of DNA synthesis.

Morphogenesis was reduced by increasing UV doses; with caffeine less than $7 \%$ of the embryos developed normally. These results may indicate an error-prone repair mechanism.
\end{abstract}

Generally, developing egg cells are characterized by short cleavage cycles, about $1 \mathrm{~h}$, without a G1 phase during the first developmental period [cf 1, 11]. Sooner or later different cell lines arise which in close co-operation build up the embryo. Cultured mammalian cells have long division cycles, with a duration of $15 \mathrm{~h}$ or longer; the division cycle do have a G1 phase [2,5]. UV damage is repaired by these cells [17]. The question arose how early embryonic cells cope with UV-induced injury to their DNA.

Exposure of fertilized egg cells of Strongylocentrotus purpuratus [24], Echinarachnius parma [4] and Lymnaea stagnalis [11] to ultraviolet (UV) light leads to a lengthening of cleavage cycles. The effect depends on the stage of the cell cycle in which ir- radiation is applied. After UV irradiation three phases of different sensitivity were distinguished in a cleavage cycle: (1) a period of high sensitivity before the $S$ phase; (2) a transition to insensitivity during the $S$ phase, and (3) the last part of the cleavage cycle, which is insensitive to irradiation. The sensitivity with regard to the postirradiation cleavage cycle increases when irradiation is carried out at a later stage of DNA replication. Irradiation during the post-replicative phase of the cell cycle has its maximum effect on the next cleavage cycle $[24,4,11]$. It was concluded that the primary target of UV light causing lengthening of cleavage cycles is the nuclear DNA. The lesions in the non-replicated part of the DNA prolong the irradiated cleavage 
cycle, whereas the lesions in the already replicated part of the DNA extend the forthcoming (post-irradiation) cleavage cycle. Since the then following cleavage cycle is of normal duration, these observations suggest that the DNA damage is efficiently repaired in the egg cells.

According to Graham et al. [9] the lengthening of the cleavage cycles is caused by inhibition of DNA synthesis. Similar observations have been described after UV exposure of cultured mammalian cells $[2,7$, 21]. Contradictory results, obtained by Cook [4] and Labordus [11], suggested a UV-induced extension of the $\mathrm{G} 2$ phase in the cleavage cycles of $E$. parma and $L$. stagnalis, respectively.

For mammalian cells it is known that DNA replication on a damaged template after UV irradiation is caffeine-sensitive $[17,22]$. This effect is attributed to the interference of caffeine with a post-replication repair mechanism [17]. Since it is possible that post-replication repair is involved in the recovery of irradiated egg cells, the question can be raised whether the delay of cleavages after UV-irradiation is caffeinesensitive.

In this report experiments will be described in which the effect is studied of caffeine on the duration of cleavage cycles in irradiated egg cells of L. stagnalis. An additional lengthening of cleavage cycles after treatment with caffeïne suggests that the UV-induced extension of cleavage cycles must be attributed to a caffeinesensitive repair mechanism.

\section{MATERIAL AND METHODS}

\section{The egg material}

The egg material of $L$. stagnalis was obtained from first generation snails descending from specimens collected from ditches near the laboratory. The egg capsules were freed from adhering jelly on moistened filter paper. Groups of synchronized egg cells of an egg mass were obtained by collecting the eggs in which the cleavage began almost simultaneously (within \pm 2 $\min$ ). The egg cells were orientated on agar bottoms, as described previously [11]. The animal hemispheres, with the nucleus near the egg surface, were turned towards the UV source. The experiments were carried out in a temperature room $\left(25^{\circ} \pm 1^{\circ} \mathrm{C}\right)$ with subdued illumination to prevent photoreactivation.

\section{Irradiation}

UV-light was obtained from a low pressure mercury lamp (Philips, TUV, $15 \mathrm{~W}$ ), emitting UV light predominantly of $254 \mathrm{~nm}$. The dose rate at the level of the egg capsules was $0.8 \mathrm{Jm}^{-2} \mathrm{sec}^{-1}$. The capsule fluid absorbs UV light; the varying thickness of the fluid causes variations in the UV light reaching the egg cells.

\section{Caffeïne treatment}

The egg capsules were treated in $2.5 \mathrm{ml} 3 \times 10^{-3} \mathrm{M}$ caffeine in tap water (copper-free). In order to prevent dilution of the caffeine by the egg capsules, not more than ten egg capsules were treated in $2.5 \mathrm{ml}$ caffeine solution.

\section{The experimental procedure}

In all experiments synchronized and oriented egg cells were irradiated during the $\mathbf{G} 2$ phase of the 2 nd cleavage cycle, which is about half-way the 1 st and the 2nd cleavage.

In the first set of experiments (fifteen egg masses), irradiation ( $3 \mathrm{~min}$ ) was immediately followed by caffeîne treatment. The egg cells were synchronized again at the beginning of the 2nd cleavage, if the caffeine treatment is continued during the 3 rd cleavage cycle. At different moments during the irradiated (2nd) and the post-irradiation ( $3 \mathrm{rd}$ ) cleavage cycle the caffeine treatment was terminated by transferring the egg cells to an excess of tap water.

In a second set of experiments different UV-doses were applied (1.5, 3 and $5 \mathrm{~min})$. Immediately after irradiation the egg cells were treated with caffeine until the beginning of the 3rd cleavage.

Three control batches from each egg mass were taken: (1) twenty non-treated egg cells for which the durations of the 2 nd, 3rd and 4th cleavage cycles were determined; (2) ten egg cells treated with caffeïne between half-way the $\mathrm{G} 2$ phase (about $50 \%$ of the duration of the cleavage cycle [1]) of the 2nd cleavage cycle and the beginning of the 3rd cleavage; the durations of the 2nd, 3rd and 4th cleavage cycles were determined; (3) five oriented egg cells UV-irradiated half-way the $G 2$ phase of the 2 nd cleavage cycle; the durations of the $2 \mathrm{nd}$, $3 \mathrm{rd}$ and 4 th cleavage cycles were determined.

These embryos were inspected daily until normal morphogenesis was completed. The difference between the delays of two successive cell divisions expressed in minutes is a measure of the extension of the interjacent cleavage cycle. 


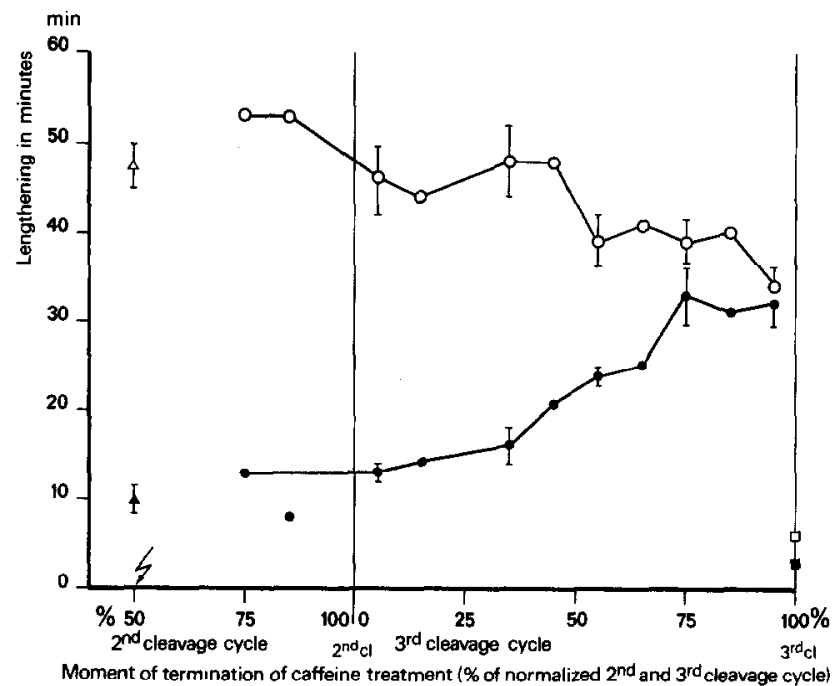

Fig. 1. Oriented and synchronized egg cells of $L$. stagnalis irradiated during the G2 phase of the 2 nd cleavage cycle (3 min). Caffeïne treatment immediately after irradiation, and terminated at different times. The lengthening of the 3rd $(\mathrm{O}-\mathrm{O})$ and the 4 th $(-0)$ cleavage cycles plotted as a function of the moment of termination of the caffeine treatment. UV control: $\triangle$, $\Delta$, effect on the $3 \mathrm{rd}$ and 4 th cleavage cycles. Caffeine control; $\square$, $\square$, effect on the $3 \mathrm{rd}$ and the 4th cleavage cycles; $\zeta$, UVirradiation. Vertical lines, $95 \%$ confidence intervals of the mean. Details of method and description in text.

\section{Representation of the results}

L. stagnalis produces egg masses with a limited number of egg cells, 120-160 as a rule; for each experiment several egg masses had to be used. The duration of corresponding cleavage cycles varies considerably in different egg masses (65-95 min [11]); within one egg mass the duration of a certain cleavage cycle is the same for all egg cells. In order to compare the experiments, the time between two divisions is set at $100 \%$. The moments of irradiation and termination of caffeine treatment are expressed as percentages of the normalized cleavage cycles and are therefore comparable as to the stage of the cell cycle in different egg masses. However, this relation is lost when the (3rd) cleavage cycle is lengthened by irradiation, as it is uncertain whether the lengthening of the cleavage cycle is the result of a proportional lengthening of each of its phases.

\section{RESULTS}

To determine whether there is a caffeinesensitive period during a cleavage cycle, egg cells were irradiated at about $50 \%$ of the 2nd cleavage cycle, i.e. during the G2 phase. Immediately after irradiation the egg cells were treated with caffeïne $\left(3 \times 10^{-3} \mathrm{M}\right)$. Treatment was terminated at different stages of the 2nd and of the 3rd cleavage cycle, and the extension was established of the 3 rd and of the 4th cleavage cycle.

Previous experiments indicated that irradiation at $50 \%$ of the 2nd cleavage cycle did not lengthen the irradiated cycle [11]. As shown in fig. 1 the post-irradiation cleavage cycle, the $3 \mathrm{rd}$, was lengthened by 47 min (cf the UV control). The next cleavage cycle, the 4 th, was lengthened by about $10 \mathrm{~min}$. The non-irradiated egg cells (the caffeïne control) were treated from $50 \%$ of the 2 nd cleavage cycle until the beginning of the 3 rd cleavage. This treatment, exceeding the caffeine treatment of the irradiated egg cells, caused the 3rd cleavage cycle and the 4th cleavage cycle each to be extended by about $5 \mathrm{~min}$ (cf the caffeine control of fig. 1); more than $95 \%$ of the embryos developed normally (table 1 ).

The effect of caffeine on the duration of the 3 rd cleavage cycle of irradiated egg cells shows a tendency to decreasing extension when later stages were involved in the treatment (fig. 1).

As to the 4th cleavage cycle, the lengthening slightly increased during the first $35 \%$ of the duration of the (lengthened) 3rd cleavage cycle. The extension of the 4 th cleavage cycle, however, was even more pronounced after caffeïne treatment until 
Table 1. The effect of caffeine on irradiated egg cells

\begin{tabular}{|c|c|c|c|}
\hline \multirow{3}{*}{$\begin{array}{l}\text { Caffeïne } \\
\text { control }\end{array}$} & \multicolumn{2}{|c|}{ Extension (min) } & \multirow{2}{*}{$\begin{array}{l}\text { Normal } \\
\text { devel- } \\
\text { opment } \\
(\%)\end{array}$} \\
\hline & $\begin{array}{l}\text { 3rd cleavage } \\
\text { cycle }\end{array}$ & $\begin{array}{l}\text { 4th cleavage } \\
\text { cycle }\end{array}$ & \\
\hline & 5 & 10 & 96 \\
\hline \multicolumn{4}{|l|}{ UV-control } \\
\hline $\begin{array}{l}1.5 \min \\
3 \mathrm{~min}\end{array}$ & 25 & 13 & 58 \\
\hline $\begin{array}{l}3 \mathrm{~min} \\
5 \mathrm{~min}\end{array}$ & 43 & 11 & 25 \\
\hline $5 \mathrm{~min}$ & 63 & 12 & 8 \\
\hline \multicolumn{4}{|l|}{ UV+caffeïne } \\
\hline $1.5 \mathrm{~min}$ & 48 & 15 & 7 \\
\hline $3 \min$ & 52 & 42 & 0 \\
\hline $5 \mathrm{~min}$ & 53 & 53 & 7 \\
\hline
\end{tabular}

Oriented egg cells irradiated at about $50 \%$ of the 2 nd cleavage cycle (UV-control), or irradiated at $50 \%$ of the 2nd cleavage cycle followed by a caffeine treatment $\left(3 \times 10^{-3} \mathrm{M}\right)$ until 3rd cleavage (UV+caffeïne). The caffeine control was treated with caffeine between $50 \%$ of the 2 nd cleavage cycle and the 3 rd cleavage. The extensions of the 3 rd and the 4 th cleavage cycles were determined, as well as the course of morphogenesis.

$70 \%$ of the duration of the (lengthened) 3 rd cleavage cycle. Beyond $70 \%$ of this cycle caffeïne did not further increase the extension of the 4th cleavage cycle.

In a parallel experiment (five egg masses; results not shown) the egg cells were treated with $4 \times 10^{-3} \mathrm{M}$ caffeinne. The abovedescribed decreasing extension of the 3rd cleavage cycle, and the increasing effect on the duration of the 4th cleavage cycle were even more pronounced.

In a second set of experiments different doses of UV-light were applied (1.5, 3 and $5 \mathrm{~min}$ ). Immediately after irradiation, at about $50 \%$ of the 2 nd cleavage cycle, the egg cells were placed in a caffeïne solution $\left(3 \times 10^{-3} \mathrm{M}\right)$ until the beginning of the $3 \mathrm{rd}$ cleavage, and the durations of the $3 \mathrm{rd}$ and the 4th cleavage cycles were determined. The duration of the 3rd cleavage cycle of the egg cells not treated with caffeine (UV control) increased with increasing dose; the 4th cleavage cycle of these egg cells was lengthened by about $12 \mathrm{~min}$. After caffeïne treatment the 3 rd cleavage cycle was lengthened by about $50 \mathrm{~min}$, irrespective of the applied UV dose; the extensions of the 4th cleavage cycle increased with increasing dose of UV light (table 1). These results suggest that in the presence of caffeinne the delayed progression through the 3 rd cleavage cycle is independent of the number of lesions in the DNA. Fig. 1 and table 1 show contradictory results: the lesser extension of the 3rd cleavage cycle by caffeìne, as shown in fig. 1 , is also found after 5 min irradiation, but not after irradiation of 1.5 and 3 min (table 1 ).

Table 1 shows that normal development decreases with increasing UV doses. Normal development of the egg cells is hardly affected by caffeine treatment. Irrespective of the UV dose, caffeine reduces the normal development to $7 \%$ or less.

\section{DISCUSSION}

Previous experiments with egg cells of $L$. stagnalis indicate that UV light, applied during the G2 phase, extends only the first post-irradiation cleavage cycle; the duration of the next cleavage cycles proved to be normal $[11,13]$. It is shown that the extension of the 3rd cleavage cycle depends on the UV dose (table 1). This suggests that the injured DNA is repaired during the lengthened cleavage cycle, and that the extension thereof depends on the degree of damage at the beginning of the cycle.

Caffeine did neither extend the 3rd cleavage cycle of the non-irradiated egg cells nor that of the egg cells irradiated for 3 and 5 min. Hence, caffeine did not affect the progression through the 3 rd cleavage cycle. Similar results were obtained with rodent 
cells, though caffeine causes a small delay in the non-irradiated cells [6]. In UVirradiated mammalian cells, the lengthening of a division cycle is caused by a delay in the progression of the cells through the $S$ phase $[2,7]$. Caffeine did not delay the progression through the $\mathbf{S}$ phase after irradiation $[6,19]$. These results suggest that also in mammalian cells caffeine does not affect the progression of the cells through the division cycle after irradiation. On the contrary, in UV-irradiated rodent cells [19], and in alkylated cells [23], caffeine reduces the lengthening of the $S$ phase with respect to the irradiated cells that were not treated with caffeine. The lesser extension of the 3rd cleavage cycle in Lymnaea eggs, which probably results from a lesser prolongation of the $S$ phase (see below), is indicated in fig. 1. However, this effect may vary, because table 1 shows that the same treatment causes an extension of the 3rd cleavage cycle. A similar variation was also observed in cultured Chinese hamster cells [19].

The present experiments show that caffeine treatment of UV-irradiated egg cells extend the 4th cleavage cycle, and progressively more when later stages of the extended 3rd cleavage cycle are included. This pattern of sensitivity to caffeïne suggests that impairment of the repair of DNA lesions is mainly effected during the 3rd cleavage cycle. As a result the extension of the 4th cleavage cycle is determined by the number of lesions remaining in the DNA after the 3rd cleavage cycle.

These results may be interpreted as follows. The lesions caused in the DNA and leading to a lengthening of the cleavage cycles are most probably pyrimidine dimers $[12,15]$. The extension of the cleavage cycle may be attributed to the prolongation of the $S$ phase after inhibition of DNA replication, as was observed in cultured mammalian cells $[2,7,17,21]$. With the applied UV dose most of the lesions have been repaired before the beginning of the next cleavage. The presence of caffeine inhibits the repair of DNA damage, and this brings about the lengthening of the next (4th) cleavage cycle, proportional to the number of lesions at the beginning of this cycle. In the absence of a G1 phase in Lymnaea eggs [1] the presence of lesions in the DNA may interfere with the initiation of DNA synthesis, and the progression may depend on the recovery of the initiation of DNA synthesis. However, this initiation seems to be independent of caffeine, as the 3 rd cleavage cycle is not extended. In mammalian cells indications have been found of a second phase in recovery of the DNA synthesis in which DNA lesions may become innocuous. These lesions remain in the next cycle, without disturbing the progression of the DNA replication [3, 18, 20]. A similar mechanism may affect the egg cells of $L$. stagnalis. The caffeine sensitivity of the repair process, in accordance with observations in mammalian cells $[8$, $16,17,22]$, suggests that the post-replication mode of repair is the most important mechanism for this process. Our results might be explained by assuming an effect of caffeine on this second phase of the recovery of DNA synthesis, leading to DNA lesions that continue to have a progressive inhibiting effect at the beginning of the next (4th) cleavage cycle.

More difficult to explain is the effect of caffeïne on the 3rd cleavage cycle in egg cells irradiated for $1.5 \mathrm{~min}$. An effect on the initiation of DNA synthesis seems unlikely, as caffeine did not extend the 3rd cleavage cycle after irradiation for 3 and $5 \mathrm{~min}$.

The biological relevance of the repair of UV damage of the DNA is shown by the 
morphogenesis of the irradiated eggs. Normal development seems to be related to the duration of the extension of the 3rd cleavage cycle; the 4 th cleavage cycle is slightly extended, independently of the applied UV dose. This might indicate to an error-prone repair during the 3 rd cleavage cycle, which is possibly the cause of the previously observed abnormal anaphase movement of the chromosomes [14]. The effect of UV light is aggravated by caffeine. Chromosomal aberrations, increased by caffeïne, are an important cause of reproductive death of different cell types [10]. The repair of the pyrimidine dimers is a prerequisite for normal development. This can be inferred from the photoreactivation of the effect of UV light. The photoreactivating light was most effective if it was applied before or during the first $30 \%$ of the lengthened $S$ phase of the 3 rd cleavage cycle. These experiments showed that normal development was enhanced if the dimers were monomerized before they become involved in the replication of the DNA [15].

The authors thank Professor D. Bootsma, Erasmus University, Rotterdam, for his comments on the manuscript, and Dr L. Boomgaart, Zeist, for improving the grammar and style.

\section{REFERENCES}

1. van den Biggelaar, J A M, J embryol exp morphol 26 (1971) 351.

2. Bootsma, D \& Humphrey, R M, Mutat res 5 (1968) 289.

3. Buhl, S N, Setlow, R B \& Regan, J D, Biophys j 13 (1973) 1265

4. Cook, J S, Exp cell res 50 (1968) 627.

5. Domon, M \& Rauth, A M, Radiat res 35 (1968) 350.

6. - Ibid 39 (1969) 207.

7. - Ibid 40 (1969) 414.

8. Doniger, J, J mol biol 120 (1978) 43.

9. Graham, C F, Arms, K \& Gurdon, J B, Dev biol 14 (1966) 349 .

10. Kihlman, B A, Sturelid, S, Hartley-Asp, B \& Nilsson, K, Mutat res 26 (1974) 105.

11. Labordus, V, Proc kon ned akad wetensch $C 73$ (1970) 366 .

12. - Ibid C73 (1970) 382.

13. - Ibid C73 (1970) 397 .

14. - Ibid C73 (1970) 477

15. Labordus, V \& Deumer, H. In preparation.

16. Lehmann, A R, Life sci 15 (1974) 2005.

17. - Radiation and cellular control processes (ed J Kiefer) p. 147. Springer Verlag, Berlin (1976).

18. Lehmann, A R \& Kirk-Bell, S, Eur j biochem 31 (1972) 438.

19. - Mutat res 26 (1974) 73.

20. Meyn, R E \& Humphrey, R M, Biophys j 11 (1971) 295.

21. Painter, R B, Photophysiology (ed A C Giese) vol. 5. Academic Press, New York and London (1970).

22. Park, S D \& Cleaver, J E, Nucl acids res 6 (1979) 1151.

23. Roberts, J J, Adv in radiat biol 7 (1978) 221.

24. Rustad, R C, Exp cell res 21 (1960) 59.

Received February 3, 1982

Revised version received April 20, 1982

Accepted April 23, 1982 